\title{
Sports mega-events in Brazil: an account of the Brazilian government's actions
}

\author{
Alberto Reinaldo Reppold Filho ${ }^{1, *}$, Cassia Damiani ${ }^{2}$, Patrícia Silveira Fontana ${ }^{1}$
}

1 Center for Olympic and Paralympic Studies, Federal University of Rio Grande do Sul, Brazil

2 Institute of Physical Education and Sports, Federal University of Ceará, Brazil

* Corresponding author: alberto.reppold@ufrgs.br

\begin{abstract}
During the period from 2007 to 2016, Brazil hosted a number of major sporting events, including the 2014 FIFA World Cup and the Rio 2016 Olympics. The planning and organization of these sporting events, from the bidding process to the monitoring of the legacy, required a great involvement of the Brazilian government. The purpose of this study is to present an account and an assessment of the Brazilian government's actions in relation to these events. The research involved an analysis of government documents in particular those produced by the Ministry of Sport. The results indicated that, apart from the implementation of a policy to promote sport in the country and achieve high-level results in international competition, the engagement of the Brazilian government in such sports mega-events was part of a broad policy focused on international relations, urban change and economic and social development.
\end{abstract}

KEYWORDS

Olympic Games; FIFA World Cup; sport policy

DOI

10.14712/23366052.2018.3

C 2018 The Authors. This is an open-access article distributed under the terms of the Creative Commons Attribution License (http://creativecommons.org/licenses/by/4.0), which permits unrestricted use, distribution, and reproduction in any medium, provided the original author and source are credited. 


\section{INTRODUCTION}

The major sporting events that took place in Brazil from 2007 to 2016, especially the 2014 FIFA World Cup and the Rio 2016 Olympics, aroused the attention and interest of different segments of Brazilian society and abroad. Sports organizations (Fédération Internationale de Football Association, 2014a, 2014b), international agencies (Banco Interamericano de Desenvolvimento, 2013), public institutions (Fundação Instituto de Administração, 2009; Instituto de Pesquisa Econômica Aplicada, 2008), private consulting firms (Ernst \& Young Terco, 2011), the business sector (Sport Business, 2011), and community associations (Comitê Popular da Copa e das Olimpíadas do Rio de Janeiro, 2015), among other groups and organized sectors, examined and discussed the implications of these events in their spheres of interest.

Analyses and interpretations of the planning, organization and implementation of these events, and their economic and social impacts and legacies, were carried out by research studies of various areas and, just to mention the issues that received most attention, focused on tourism, urban planning, sport facilities, environment and sustainability, volunteering, and evictions and displacements of low income communities (Mataruna-dos-Santos \& Pena, 2017; International Council of Sport Science and Physical Education, 2016; Boykoff, 2016; Deslandes, Dacosta, \& Miragaya, 2015; Santos Júnior, Gaffney, \& Ribeiro, 2015; Mascarenhas, Bienenstein, \& Sánchez, 2011; Da Costa, Corrêa, Rizzuti, Villano, \& Miragaya, 2008).

There is, however, a dearth of studies on the role played by the Brazilian government in such events, especially the actions carried out to support the candidacy for and to engage in the organization of the FIFA World Cup and the Rio Olympics. By consulting governmental documents, this study attempts to provide an account and an assessment of the Brazilian government's actions in respect to such events, particularly those of the Ministry of Sport, the main protagonist at the federal level, in the bidding for and the organization and implementation of the sports mega-events held in the country.

\section{THE DECADE OF SPORTS MEGA-EVENTS IN BRAZIL}

It is difficult to state with certainty when the Brazilian government decided to fully engage and support the bid and organization of these mega-events carried out in the country from 2007 to 2016, a period of time that became known in Brazil as the decade of sports mega-events. In this period, the city of Rio de Janeiro and other large Brazilian cities hosted several large-scale sport events: the Pan American Games and Parapan American Games in 2007, the Military World Games in 2011, the Confederations Cup in 2013, the FIFA World Cup in 2014, and the Olympics and Paralympics in 2016.

Even though some initiatives were already under way in previous years, it was in 2000, during the bidding for the 2007 Pan and Parapan American Games (Brasil, 2003), that the Brazilian government started to play a more important role in the decision making process on such sport events.

The initiative for hosting the 2007 Pan American Games was taken by the Brazilian Olympic Committee (COB) in conjunction with the Municipality of Rio de Janeiro. It was part of a long-term plan to bring the Olympics to the city. Rio de Janeiro 
had already unsuccessfully applied to host the Olympics on two occasions (1936 and 2004). Concerning the latter, the city was eliminated at the preliminary stage. In 1999, after the bid failure for the 2004 Olympics, the COB decided to change its strategy (Brasil, 2008a, p. 14). The focus was now on hosting the Pan American Games, since success in organizing a major continental sport event would show to the international sport community that the city was in a good condition to hold great sporting events. As a consequence, the COB gave up the idea of bidding for the 2008 Olympics. An important step in this new direction was made in 2000 when the COB and the $\mathrm{Mu}-$ nicipality of Rio de Janeiro announced a strategic plan for the candidacy of the 2007 Pan American Games and 2012 Olympics. Some months later, at a meeting of the Pan American Sports Organization (PASO), Carlos Arthur Nuzman, President of the COB, officially presented the city's bid for the 2007 Pan American Games.

The idea to host the Pan American Games received support from the Brazilian government. In May 2000, at the Opening Ceremony of the General Assembly of the Association of National Olympic Committees (ANOC), held in Rio de Janeiro, Fernando Henrique Cardoso, Brazilian President at the time, expressed his support for the 2007 Pan American bid, also stating that the Federal Government would back Rio de Janeiro's candidacy for the 2012 Olympics, should the city decide to submit a bid (Brasil, 2000, p. 405).

In August 2002, in Mexico City, when Rio de Janeiro was granted the right to host the event, Fernando Henrique Cardoso had agreed with the conditions set by PASO, and had guaranteed the Brazilian government's financial support for the Games according to the budget proposed by the COB. The estimated cost of the Pan was US $\$ 186.2$ million for the organization of the event and for infrastructural work, including the renovation and construction of sports facilities. Of the total cost, US $\$ 41.3$ million (22\%) was the responsibility of the Brazilian government (Brasil, 2008a, p. 21).

The bid took place in a year of presidential elections in Brazil. To mark the Brazilian government's commitment to the Games, the four presidential candidates recorded testimonials that were presented at the PASO meeting in Mexico City, stating that, if elected, they would maintain the commitment to hold the Games in Rio de Janeiro. Thus, when President Luiz Inácio Lula da Silva took over the presidency in January 2003, he went ahead with the preparations for the event, together with the COB and Rio de Janeiro state and city governments. One of the positive points of Rio de Janeiro's bid was the suggestion to host the Parapan American Games just after the Pan, using the same structure and organization, something that had not happened in previous editions of the games. So, with victory in the candidacy, the country took on the responsibility of organizing two continental events.

Thus, having on the one hand a city planning conception dating back to 1993 and 1994, when the Rio de Janeiro City Strategic Plan (Vainer, 2013, p. 59) was elaborated, and on the other hand the understanding that sports mega-events are drivers of urban change, public authorities, among them the Brazilian government, took steps to create conditions to ensure that these sporting events would take place in the city (Brasil, 2006a).

Throughout the preparation period, the 2007 Pan and Parapan Games were regarded with skepticism and distrust by various segments of the Brazilian population. Few would have bet that the country would be able to hold such an important event. 
Brazil had no tradition of organizing sporting events of this size, the urban services needed to host such events were almost everywhere of poor quality, and public works were performed at above market prices and rarely completed on time. In addition, the country suffered from a lack of planning capacity and excessive bureaucracy. The Games, however, were a commitment assumed by Brazil and also, in the view of many, an opportunity to promote changes in the city of Rio de Janeiro.

In terms of sports results and population support, the $\mathrm{COB}$ and the Brazilian Government considered the Games a success. Soon after the Pan, an opinion poll conducted by IBOPE (a Brazilian survey agency) revealed a favourable view of the event among the Brazilian population over 16 years of age: $81 \%$ considered the Games "well organized" and $73 \%$ that the resources to promote them were "well applied" (IBOPE, 2007, p. 56 and 92). These evaluations were not shared by other segments of Brazilian society, which pointed to problems of planning and organization, lack of popular participation in the decision-making process and, after the Games, under-utilized sports facilities. The main criticism focused on the urban works that were included in the city plan for the 2007 Pan but were not carried out, the high costs of the event, and corruption and suspicion of misappropriation of public money in the contracts for the works and services related to the Games. The final report published by the Ministry of Sport showed a total cost of $\mathrm{R} \$ 3.09$ billion of which $\mathrm{R} \$ 1.60$ billion (52.3\%) was funded by the Brazilian government (Brasil, 2008a, p. 81). (NB: R $\$ 4=€ 1$ )

In spite of criticisms, the realization of these events created a favourable environment with international sports organizations for the Rio de Janeiro bid to host the 2016 Olympics. The Brazilian government's understanding that the 2007 Pan and Parapan brought positive results also reinforced the arguments in favour of Federal Government support to the Brazilian Football Confederation's (CBF) bid for the 2014 FIFA World Cup. In this respect, since November 2006 a task group of the Federal Government established by President Lula was in charge of elaborating a strategic plan and defining actions, within the competence of the Federal Government, in order to comply with the requirements established by FIFA so that Brazil could apply for the 2014 World Cup (Brasil, 2006b).

After the Pan and Parapan experience, there was greater agreement at the Federal Government level that, if well planned and executed, the Olympics and the World Cup could generate benefits for Brazil, raising the country's image to the world, attracting foreign investment, furthering economic development, and promoting social and urban changes. In analysing the strategic agenda of the Brazilian Presidency, it is observed that since the 2007 Pan and Parapan, sport came to be one of the central factors in social and economic development for the government (Brasil, 2008b, 2010, 2016).

The decision to bid for the 2016 Olympics was taken at the Assembly of COB in September 2006, supported by the technical evaluation of Event Management Services (EKS), an international consulting firm hired by the COB to issue an expert report on the proposal of Rio de Janeiro. For EKS, the experience of organizing the Pan and Parapan, and the sports facilities built for these events, would give to Rio de Janeiro an excellent starting point for the bid. At Federal level, the Ministry of Sport was given the task of carrying out such an attempt and of coordinating the Brazilian government's actions, since it had been the main player in the Pan and Parapan Games. 
On October 2007, Joseph Blatter announced Brazil as the host country of the 2014 FIFA World Cup. With the right to host the event, the Brazilian government put into practice its plan to make the event a catalyst for change in various policy areas.

As preparations for the World Cup were taking place, the Brazilian government was involved with the Rio de Janeiro bid for the 2016 Olympics. Studies conducted by Brazilian and foreign institutions helped in the decision of the Federal Government over the model to be adopted for the Olympics in Brazil. In view of the reports examined, the Brazilian government chose to follow the example of Barcelona.

In this respect, since the early years of his presidential mandate, Luiz Inácio Lula da Silva, a football afficianado, took sport as an ally in his external policy. In 2004, at his request, the $\mathrm{CBF}$ took the national football squad to Port-au-Prince, in Haiti, to play a friendly match with the Haiti national team. The match was organized by the United Nations with the aim of promoting peace and reconciliation. At the time, Brazilian troops were in Haiti as part of an international peace force after a violent revolt that led to a change in the country's government. This connection of Lula (as he is called in Brazil) with sport, and especially football, became known among journalists and academics as "ball diplomacy". Lula attended the match and, according to media reports, asked the Brazilian players, among them Ronaldo, "not to score too many goals" (British Broadcasting Corporation, 2004).

In the years that preceded the election of the host city for the 2016 Olympics, the Brazilian government engaged in many activities abroad using sport as an instrument for external policy. In 2008, a new sector within the Brazilian Ministry of Foreign Affairs was created to coordinate government actions in this area: the General Coordination for Cooperation and Interchange on Sport (CGCE). A plan was prepared for Brazilian diplomats to make contacts with IOC members, National Olympic Committee and International Sport Federation presidents, government authorities and sport personalities who could influence the voting for the 2016 Olympics. The president himself had meetings with several heads of state, attempting to gain their support for the Rio de Janeiro candidacy. He also attended the Opening Ceremony of the Beijing Olympics in 2008 and visited the London Olympic Park in April 2009 (Resende, 2010, pp. 35-36).

On 2nd October 2009, the Brazilian president delivered a speech at the 121 st IOC Session held in Copenhagen as part of Rio de Janeiro's candidacy presentation for the 2016 Olympics and just a few hours before the voting process. His speech was considered by the Brazilian media, politicians and sport leaders as decisive for Rio's victory over Madrid, Tokyo and Chicago. The international media also highlighted Lula's role in the election of Rio as host of the 2016 Olympics. On 3rd October 2009, The Telegraph, an English newspaper, depicted Lula as "the driving force behind the bid for the past three years with his strong personal and vocal commitment".

Throughout the preparation for these events, large sectors of Brazilian society resisted and even opposed the demands of the IOC and did not welcome the enormous amount of public funds to be put into its realization. One of the most critical problems identified in the accomplishment of these events was the long time spent by the government in signing contracts with private companies, especially in the area of construction and services. Brazilian legislation was very strict on these matters, with a number of required steps and deadlines that slowed down the process of contracting. In order to speed up the hiring of private companies, the Brazilian government 
proposed a new model for public contracting. The implementation of such a measure required a change in federal legislation, and only after intense debate in the National Congress was the new model approved (Brasil, 2011a). Initially planned to improve works and services related to the 2014 World Cup and the 2016 Olympics, the new regime was later extended to other areas of public administration. The Brazilian government considered this model of contracting a legacy of sports mega-events to the public management and sports of the country. For the critics of the events and the political opposition, it was a way of favouring big private companies, particularly those involved with the construction of sport facilities and urban works.

There were also governance problems, mainly in the communication and distribution of responsibilities among the three levels of government (Federal, State and Municipal), that gained relevance in the years 2011 and 2012. During this period, the Brazilian government conceived a governance model that would bring together the three levels of government, private partners and civil society. Under the executive coordination of the Ministry of Sport, the governing committees of the World Cup and the Rio 2016 Olympics and Paralympics were created. The two committees were organized in thematic chambers that brought together all sectors of federal, state and municipal governments involved in the events, having the co-responsibility of following up and executing, in each instance, the governmental commitments and projects foreseen in the matrix of responsibility of the events.

In 2011, a public consortium known as the Olympic Public Authority (APO) was formed. The purpose of the institution was to coordinate governmental actions for the planning and delivery of the works and services necessary for the Games (Brasil, 2011b). One year later, the Brazilian government created the Management Committee for the Rio 2016 Olympic and Paralympic Games (CGOlimpíadas) to define the guidelines and actions of the Federal Government in relation to these events (Brasil, 2012).

The Executive Group for the 2016 Olympic and Paralympic Games (GEOlimpíadas) was also created by the Brazilian government (Brasil, 2012). The Group was responsible for approving and coordinating the activities developed by federal administration bodies or financed with funds from the Federal Government relating to the Games, and for monitoring the implementation of the actions defined by the CGOlimpíadas.

The Ministry of Sports considered this model of governance an innovation and an important legacy for public management, intended and implemented for greater alignment, speed and economy in the execution of the processes, in order to obtain greater effectiveness in the delivery of the events. In practice, however, these measures to improve the interaction between the different levels of government did not work as expected, and problems persisted until the events were over. The same happened in relation to the interaction between the public and the private sector.

In 2013, the Confederations Cup took place in 6 large Brazilian cities. The competition to host the matches began in 2009 and ended only in 2011, when FIFA announced the venues of the tournament. The fierce dispute among Brazilian cities highlighted the importance that local leaders and governments attached to such events. The Brazilian government participated in different ways, from providing financial support for the construction of sports venues to security, telecommunications, transportation, business and tourism infrastructure. The Brazilian Agency for the Promotion of Exports and Investments (Apex-Brasil), for example, brought over international busi- 
ness executives around the tournament, with the aim of contributing to domestic job creation and income generation. This Agency acted to promote Brazilian products and services abroad and to attract foreign investment to strategic sectors of the Brazilian economy. FIFA and the Brazilian government celebrated the stadium attendance (over 50,000 people per game, on average) and the financial success of the event (Brasil, 2013).

The Confederations Cup, however, did not proceed without problems. The competition period was marked by popular demonstrations in the main cities of the country. Among the concerns of protesters were: the reduction of fares and improvement of public transport, the improvement of public safety, the fight against corruption, and greater investments in education and health. In addition, demonstrators criticized high spending on the World Cup and the Rio 2016 Olympics. Numerous clashes between police and demonstrators took place near the stadiums. The media gave visibility to the events, and the images travelled throughout the country and the world, showing the dissatisfaction of a significant part of the Brazilian population with the holding and handling of these events.

The Brazilian government, though criticizing the episodes of violence and damage to public and private property, considered the demonstrations as expressions of the democracy recently installed in the country. In response to the criticisms of World Cup and Olympics expenditures, the Executive Secretary of the Ministry of Sport stated that the legacy being built by all public and private entities involved in the planning of these events rightly contemplates the aspirations of the Brazilian population, as expressed by the demonstrators (Fernandes, 2013, p. 22).

Regarding the major sports events held in Brazil, however, there was no participation of the population in the decision-making process at any stage: bid, organization, accomplishment, or management of the legacy. In fact, the organizing committees of sports events held in Brazil have often used the results of opinion polls to justify and legitimize their actions and decisions. This procedure falls far short of what is desired for events that substantially affect people's lives and involve, as in the case of Brazil, huge public investments.

The period following the Confederations Cup was one of uncertainty over the completion of stadiums and other works planned for the 2014 World Cup. The preparations for this event required major participation from the Brazilian government, especially in terms of financial support. In the construction and renovation of the stadiums, $\mathrm{R} \$ 8.38$ billion was spent, of which $\mathrm{R} \$ 3.81$ billion was financed by the National Bank for Economic and Social Development (BNDES), R $\$ 3.95$ billion in local government investments, and $\mathrm{R} \$ 611$ million in private investments. Investments for the event totalled $\mathrm{R} \$ 27.1$ billion. This amount includes construction for urban mobility, ports, airports, security, telecommunications, tourism infrastructure and complementary facilities for the event (Brasil, 2014a).

The Football World Cup involved twelve Brazilian cities. Eighteen cities applied to host the matches, with FIFA experiencing difficulty in making their choice due to the great dispute between the candidates. To meet the pressures of the states and municipalities, and to recognise the Brazilian government's intention to promote urban change and to expose the country's large cities to the world, twelve cities were chosen instead of eight, as originally required by FIFA. 
The Brazilian government raised expectations that the Cup would bring a considerable financial return to the country, especially in tourism. The Brazilian Tourism Institute (EMBRATUR) set itself the goal of attracting 600,000 tourists to the World Cup. In October 2013, a campaign began to improve the country's image abroad, so that foreign tourists would not fear the protests, airport problems and abusive hotel prices.

For FIFA, the Cup was a financial and public success. The event had a total attendance at the stadiums of 3.42 million people, with an average of 53,500 spectators per game - the second largest totals in the history of the World Cup. (The largest was in the United States in 1994, with 3.58 million people.) In the Fan Fest, organized in the 12 host cities, 5.15 million people were present. In financial terms, the World Cup generated a total revenue of US\$4.8 million for FIFA and incurred total expenses of U\$2.2 million, thus leaving a profit of US\$2.6 million (Fédération Internationale de Football Association, 2014a, 2014b, 2015).

The Brazilian government considered the World Cup an absolute success. In the governmental view, the country won the Cup outside the football field, with investments in airports, ports, urban mobility and multipurpose arenas that remained for Brazilian society as legacies.

Dilma Rousseff, who was elected Brazilian president in 2010 to replaced Lula, stated that the success of the World Cup was a victory for the Brazilian people and government, and to highlight the greatness of the event she called it: "the Cup of Cups" (Brasil, 2014b). She said that it had been necessary to go through a delicate moment of preparation for the event, facing an atmosphere of mistrust and pessimism that the World Cup would not be successful. For the Brazilian government, this atmosphere of pessimism had been artificially created by sectors of the mainstream media with the support of Brazilian elites and political opponents who would be dissatisfied with a governmental success in the event.

In the years following the Football World Cup, attention was focused on the Olympic and Paralympic Games. The Bid proposal presented to the IOC by the Rio $2016 \mathrm{Bid}$ Committee provided for various infrastructure and social projects for the city of Rio de Janeiro, which would receive financial support from the Federal Government (Comitê de Candidatura Rio 2016, 2009). The urban and environmental legacies, considered an inseparable unit by the Brazilian government, were related to improvements in public transportation, safety, air quality, and water pollution, among others. As a consequence, many infrastructural works were carried out in Rio de Janeiro, many of them in areas of low-income communities.

The displacement and resettlement of urban populations resulting from works for the 2016 Olympics, but also for the 2014 Football World Cup, was one of the critical aspects of the arrival of sports mega-events in Brazil (Reppold Filho, 2008, 2013). Within a model of sporting events such as Olympism, that values citizenship and human rights, local populations should not be displaced to regions that present even worse conditions than those in which they already live. A fundamental aspect should be to guarantee resettlement with infrastructure in appropriate conditions, with access to schools, health, transportation, sports and leisure. Advance notice is also important, and time must be given for people to accept and to organize their changes. In poor areas, many people do not own their homes and compensation be- 
comes difficult. There are many records of violations arising from urban works and sports infrastructure for the Olympic Games and the Football World Cup in Brazil (Rolnik, 2016).

On the positive side, the sports legacy was characterized by the expansion of sports practice and physical activity for the Brazilian population. In addition, investments in financing sport projects and building sports facilities were intended to favour the performance of Brazilian athletes in future international competitions. The social legacy referred also to social inclusion and the well-being of the low-income population, especially through educational sports. The main focus was on young people.

After winning the bid for the 2016 Games, the Brazilian government prepared a strategic plan for high-performance sports. In 2009, a survey was conducted on the difficulties faced by Brazilian sport (Brasil, 2009a, 2009b). The results pointed to:

a) disarticulation of the bodies that constitute the national sports system (Federal, State, Municipality, Olympic and Paralympic Committees, Sport National Federations and sport clubs),

b) devaluation of the clubs that acted in the formation of athletes,

c) deficiencies in grassroots sport projects, particularly in schools,

d) underutilization of financial resources available for sport,

e) low quality and shortage of sports equipment and facilities.

In 2010, the Ministry of Sport organized the 3rd National Conference on Sport. This meeting, which brought together representatives of all national sports bodies, approved a recommendation for the Brazilian government: Brazil should be among the ten most successful countries in the Olympics and among the top five in the Paralympics. The idea was to make the country a sports power.

As well as an increase in the number of medals won in the Olympics and Paralympics, the notion of sports power also involved:

a) to win more medals and rank more athletes in the first eight positions in world and continental competitions,

b) to have more people and types of sports being practiced among the population,

c) to improve the level of coaches, referees and multidisciplinary teams,

d) to professionalize the management of sports organizations,

e) to develop the national sport base, and

f) to build new sport centres and training facilities, and to renew existing provision.

In the face of this challenge, the plan for high performance sport was organized on three pillars:

1) supporting the Olympic and Paralympic sports,

2) building the National Training Centres Network, and

3) expanding sport practice in the country.

To support Olympic and Paralympic sports, the Brazilian government put into practice two main projects: the Bolsa Atleta (Athlete Grant) and the Brasil Medalhas 2016 (Brazil 2016 Medals). Although the Bolsa Atleta had been running since 2005, focusing on direct financial support for athletes, the program was restructured and expanded by the Ministry of Sport. By 2015, there were about 6,100 athletes receiving this financial support, distributed in different categories of grants, from base to elite sport. In the Atleta Pódium (Athlete Podium), the top grant category, for athletes of individual sports with chances of getting medals, 261 athletes were supported. 
In 2012, to achieve the goals set for Brazilian athletes at the 2016 Olympics and Paralympics, the Brazilian government launched the Brasil Medalhas 2016. This Plan established an investment of $\mathrm{R} \$ 1$ billion in sport ( $\mathrm{R} \$ 390$ million for Training Centres and $\mathrm{R} \$ 610$ million to support athletes). This support covered all the aspects that contribute to the athlete's performance, from the costing of its coaches and multidisciplinary teams, to the acquisition of sports equipment, training in Brazil and abroad, and participation in international competitions.

In order to build a National Training Centres Network, the government set a plan to integrate the sport training facilities with the work of national sports organizations. In gymnastics, for example, 16 training centres were structured in 13 states. For wrestling, equipment was distributed across the country. Judo received a Judo Training Center and equipment for projects in all Brazilian states. Sport clubs received funds to invest in infrastructure and the preparation of athletes.

In relation to extending sports practice for the population, the Initiation Sport Centres (CIE) were created in 2014, consisting of multisport gyms for the practice of up to 13 Olympic and six Paralympic sports ( 285 units were contracted in 263 cities). The concept of the CIE was to expand the public sport provision, encouraging the practice of sports in areas of social vulnerability. The purpose announced by the Brazilian government was that such facilities would enable the democratization of access to sport to children and young people who could learn and practice, increasing their repertoire in new sports. Those who excelled would migrate their training to the Regional Training Centres and the best of those to the National Training Centres. There was also the approval of contracts for the construction and coverage of 9,817 sports courts and facilities in 3,807 cities, totalling $\mathrm{R} \$ 3.8$ billion in investments. By June 2017, many of these sport facilities were still in planning or under construction.

The Brazilian candidature for the 2016 Olympics also provided for an Olympic Education program with national impact, as did previous Games hosts (see Mountakis, 2016). This, however, did not happen as planned. This fact can be characterized as a major negative point in the government's actions. In 2014, the Organizing Committee of the Rio 2016 Olympic and Paralympic Games started the Rio 2016 Education Program, entitled 'Transforma'. It was only in July 2015, about a year before the Olympic and Paralympic Games, that the Organizing Committee signed an agreement with the Ministry of Education so that the program could be taken to the primary and secondary schools of the country's public education networks. However, the agreement was expected to close in December 2016 - so the program was planned to last only one year and a half. By the time of the Olympic Games, in August 2016, the project had reached only the Federal Capital District and 3 of the 26 Brazilian states - Rio de Janeiro, São Paulo and Minas Gerais (Tepedino, 2016). It cannot be expected that an Olympic education program of such short duration, and limited to such a few states, could have a significant impact on the Brazilian population of children and young people. 


\section{FINAL REMARKS}

The Brazilian government considered sports mega-events as opportunities for the great changes that it intended for the country, seeing their legacies as a central point in its general strategy of economic, social and political development.

Based on this understanding, the Brazilian government implemented a development plan that, under the concept of the nationalization of the benefits of major sporting events, provided for the dissemination of investments in the construction and modernization of urban infrastructure beyond Rio de Janeiro and the 12 cities that hosted the FIFA Football World Cup. The vision was that the planned benefits for the large Brazilian cities involved directly with these sport events should branch out to the surrounding areas and cities, creating a dynamic effect of the local and regional economy and promoting social benefits for the entire population.

The Brazilian government also used sports mega-events as instruments for foreign policy and public diplomacy. The intention was to improve the country's reputation and international image, increase Brazilian influence in the world and create business opportunities for its companies. Sport events were opportunities to show the world a modern, democratic, multicultural and peaceful nation, with a dynamic economy.

In relation to sports, the vision was to take Brazil to the level of a sports power. The proposal consisted of building and modernizing sports facilities and equipment, supporting the development of high-performance sports, expanding infrastructure and fostering projects for sports and physical activity throughout the country, especially for the populations of low income.

The closing of the Paralympic Games in Rio de Janeiro and the economic and political crisis that affected the country in the months leading up to the Olympic Games, which culminated in the impeachment of President Dilma Roussef, also represents the end of the so-called "decade of sports mega-events" and a cycle of Brazilian sports policy. Attention now turns to the legacy that sports mega-events have left for the country.

\section{REFERENCES}

Banco Interamericano de Desenvolvimento/Ministério do Esporte (2013). Grandes eventos esportivos e planejamento urbano. Brasília: Bid.

Boykoff, J. (2016). Power games: a political history of the Olympics. London: Verso.

Brasil (2000). Fernando Henrique Cardoso. Presidência da República. Discurso na cerimônia de abertura da XII Assembléia-Geral da Associação dos Comitês Nacionais Olímpicos.

Brasília: Biblioteca da Presidência da República. Retrieved from: http://www.biblioteca .presidencia.gov.br/presidencia/ex-presidentes/fernando-henrique-cardoso/discursos /2o-mandato/2000/55.pdf/view.

Brasil (2003). Decreto de 18 de julho de 2003. Retrieved from: http:/ /www.planalto.gov.br /ccivil_03/dnn/2003/Dnn9935compilado.htm.

Brasil (2006a). XV Jogos Pan-Americanos Rio 2007 - Planejamento Estratégico de Ações Governamentais. Brasília: Ministério do Esporte.

Brasil (2006b). Decreto de 1 de novembro de 2006. Retrieved from: http:/ /www.planalto.gov .br/ccivil_03/_Ato2004-2006/2006/Dnn/Dnn11042.htm.

Brasil (2008a). Relatório sobre os XV Jogos Pan-Americanos e III Jogos Parapan-Americanos Rio 2007 Governo Federal (Vol. 1). Brasília: Ministério do Esporte. 
Brasil (2008b). Presidente Luís Inácio da Silva. Mensagem ao Congresso 2008. Brasília: Presidência da República. Retrieved from: http://www2.planalto.gov.br/acompanhe -o-planalto/mensagem-ao-congresso.

Brasil (2009a). Coletânea Esporte e Lazer: Politicas de Estado - Caderno III: Desenvolvimento Institucional. Brasília: Ministério do Esporte.

Brasil (2009b). Políticas para o Esporte de Alto Rendimento. Brasília: Ministério do Esporte. Retrieved from: http://docplayer.com.br/14439242-Politicas-para-o-esporte-de -alto-rendimento-ricardo-leyser-secretario-nacional-de-esporte-de-alto-rendimento .html.

Brasil (2010). Presidente Luís Inácio da Silva. Mensagem ao Congresso 2010. Brasília: Presidência da República. Retrieved from: http://www2.planalto.gov.br/acompanhe-o-planalto /mensagem-ao-congresso.

Brasil (2011a). Lei no 12.462, de 4 de agosto de 2011. Retrieved from: http:/ /www.planalto .gov.br/ccivil_03/_ato2011-2014/2011/lei/112462.htm.

Brasil (2011b). Lei no 12.396, de 21 de março de 2011. Retrieved from: http:/ /www.planalto .gov.br/ccivil_03/_ato2011-2014/2011/lei/112396.htm.

Brasil (2012). Decreto de 13 de setembro de 2012. Retrieved from: http://www.planalto.gov .br/ccivil_03/_Ato2011-2014/2012/Dsn/Dsn13425.htm.

Brasil (2013). $5^{\circ}$ Balanço ds Ações do Governo Brasileiro para a Copa 2014. Retrieved from: http://www.copa2014.gov.br/sites/default/files/balanco_copa_set2013.pdf.

Brasil (2014a). Matriz de Responsabilidade Consolidada. Ministério do Esporte. Retrieved from http://www.esporte.gov.br/arquivos/assessoriaEspecialFutebol/copa2014/Matriz _consolidada_dez_2014.pdf.

Brasil (2014b). Governo faz balanço da Copa do Mundo e aborda sucesso do evento. Retrieved from: http://www.brasil.gov.br/governo/2014/07/governo-faz-balanco-da-copa-do -mundo-e-aborda-sucesso-do-evento.

Brasil (2016). Presidenta Dilma Vana Roussef. Mensagem ao Congresso, 2016. Brasília: Presidência da República. Retrieved from: http://www2.planalto.gov.br/acompanhe -o-planalto/mensagem-ao-congresso.

British Broadcasting Corporation (2004). Brazil takes on football-crazy Haiti. Retrieved from: http://news.bbc.co.uk/2/hi/americas/3575292.stm.

Comitê de Candidatura Rio 2016 (2009). Rio 2016 Cidade Candidata (Vol. 1-3). Rio de Janeiro: COB.

Comitê Popular da Copa e das Olimpíadas do Rio de Janeiro (2015). Olimpíada Rio 2016, os jogos da exclusão. Retrieved from: https://br.boell.org/sites/default/files /dossiecomiterio2015_-_english.pdf.

Da Costa, L., Corrêa, D., Rizzuti, E., Villano, B., \& Miragaya, A. (Eds.) (2008). Legados de megaeventos esportivos. Brasília: Ministério do Esporte.

Deslandes, A., Dacosta, L. P., \& Miragaya, A. (Eds.) (2015). O futuro dos megaeventos esportivos. Rio de Janeiro: Engenho Arte e Cultura. Retrieved from: http://correrbem.org.br /wp-content/uploads/2015/06/The-Future-of-Sports-Mega-events-new-book-on -Agenda-2020.-2015_06_15.pdf.

Ernst \& Young Terco (2011). Sustainable Brazil: social and economic impacts of the 2014 World Cup. Branding and Communication Department Ernst \& Young Brazil.

Fédération Internationale de Football Association (2014a). Sustainability report: 2014 FIFA World Cup Brazil. Retrieved from: https://resources.fifa.com/mm/document/afsocial /general/02/50/92/69/sustainabilityreportofthe2014fwc_neutral.pdf.

Fédération Internationale de Football Association (2014b). The 2014 Fifa World Cup in Numbers. Retrieved from: http://resources.fifa.com/mm/document/tournament/competition /02/44/29/89/fifaworldcupinnumbers_120714_v7_eng_neutral.pdf. 
Fédération Internationale de Football Association (2015). Financial Report 2014. Retrieved from: http://www.fifa.com/mm/document/affederation/administration/02/56/80/39 /fr2014weben_neutral.pdf.

Fernandes, L. (2013). Copa e olimpíadas para quem? O legado dos grandes eventos para o desenvolvimento do Brasil. Revista Princípios, 127, 17-22.

Fundação Instituto de Administração (2009). Estudo de impactos socioeconômicos potenciais da realização dos Jogos Olímpicos na cidade do Rio de Janeiro em 2016 - Relatório Final. São Paulo: FIA/FIPE.

IBOPE (2007). Pesquisa de opinião pública sobre o Ministério do Esporte. IBOPE.

Instituto de Pesquisa Econômica Aplicada (2008). Leitura econômica dos Jogos Olímpicos: financiamento, organização e resultados. Rio de Janeiro: IPEA.

International Council of Sport Science and Physical Education (2016). Special Feature - The Olympics and Paralympics in Brazil: who takes the prize? Bulletin: Journal of Sport Science and Physical Education, 70, May 2016.

Mascarenhas, G., Bienenstein, G., \& Sánchez, F. (2011). O jogo continua: megaeventos esportivos e cidades. Rio de Janeiro: EdUERJ.

Mataruna-dos-Santos, L. J., \& Pena, B. G. (2017). Mega Events Footprints: Past, Present and Future. Rio de Janeiro: Engenho.

Mountakis, C. (2016). Olympic Education in all Greek Schools - adoption and abandonment. Acta Universitatis Carolinae. Kinanthropologica, 52(2), 41-55.

Reppold Filho, A. R. (2008). Regeneração Urbana e Direitos do Cidadão: o caso dos Jogos Olímpicos de Atlanta 1996. In: Da Costa, L., et al. (Eds.), Legados de Megaeventos Esportivos (pp. 175-188). Brasília: Ministério do Esporte.

Reppold Filho, A. R. (2013). Impactos e legados dos megaeventos esportivos. Revista Princípios, $127,12-16$.

Resende, C. A. R. (2010). O esporte na política externa do governo Lula: o importante é competir? Meridiano, 47(11), 35-41.

Rolnik, R. (2016) Jogos Olímpicos e direito à moradia adequada. Ciência e Cultura, 68(2), $31-36$.

Santos Júnior, O. A., Gaffney, C., \& Ribeiro, L. C. Q. (2015). Brasil: os impactos da Copa do Mundo de 2014 e das Olimpíadas de 2016. Rio de Janeiro: Observatório das Metrópoles.

Sport Business (2011). Copa do Mundo 2014 e Olimpíadas 2016: oportunidades e negócios no Brasil. Encontro de gestores de esporte e lazer, São Paulo.

Tepedino, C. (2016). The Rio 2016 Education Programme “Tranforma”. Second International Colloquium of Olympic Studies and Research Centres (pp. 4-5). Porto Alegre: PUCRS.

The Telegraph (2009). Brazil's weeping President Luiz Inacio Lula da Silva revels in 2016 Olympics vote. The Telegraph, 3 Oct 2009. Retrieved from: https://www.telegraph.co.uk /sport/olympics/news/6257463/Brazils-weeping-President-Luiz-Inacio -Lula-da-Silva-revels-in-2016-Olympics-vote.html.

Vainer, C. (2013). Cidade de exceção: reflexões a partir do Rio de Janeiro. In: Machado, C. R. S., Santos, C. F., Araujo, C. F., \& Passos, W. V. (Eds.), Conflitos ambientais e urbanos: debates, lutas e desafios. Porto Alegre: Evangraf. 